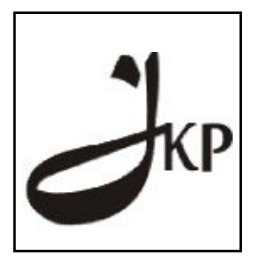

Jurnal Konseling dan Pendidikan

ISSN Cetak: 2337-6740 - ISSN Online: 2337-6880

http://jurnal.konselingindonesia.com

Volume 3 Nomor 1, February 2015, HIm 22-28

Info Artikel:

Diterima 09/02//2015

Direvisi 18/02/2015

Dipublikasikan 28/02/2015

\title{
Permasalahan yang Dialami Lansia dalam Melakukan Penyesuaian Diri di Panti Sosial dan Implikasinya terhadap Layanan Bimbingan dan Konseling (Studi Deskriptif terhadap Lansia di PSTW Sabai Nan Aluih Sicincin)
}

Fitri Febriani, Syahniar \& Zikra

Universitas Negeri Padang

\begin{abstract}
Changes that occur when entering old age requires a new kind of adjustment, that adjustments to themselves and to the environment. For the elderly who live in social institutions they require the ability to adjust to life in social institutions. In fact there are elderly people who do not have the ability to adapt in the social institutions. This study aims to determine the problems in the elderly make adjustments in social institutions. This research is descriptive. The sample of 31 people. The findings show that 1) $21.75 \%$ of elderly have problems in personal adjustment includes adjustments to the physical changes, and adjustments to the psychological condition, 2) $22.81 \%$ of elderly have problems in social adjustment includes adjustment of relationships with fellow residents, adjusting relationships with nursing board, adjustment of relationships with family, and adjustments to regulation of social institutions.
\end{abstract}

Keyword: Adjustment problems of elderly, social institutions.

Copyright @ 2015 IICE - Multikarya Kons (Padang - Indonesia) dan IKI - Ikatan Konselor Indonesia - All Rights Reserved

Indonesian Institute for Counseling and Education (IICE) Multikarya Kons

\section{PENDAHULUAN}

Setiap manusia akan mengalami masa tumbuh dan berkembang dalam rentang kehidupannya. Dalam perkembangan manusia terjadi perubahan-perubahan yang sedikit banyak bersifat dinamis namun tidak dapat diulangi. Perubahan-perubahan tersebut dapat terjadi dari segi fisik maupun psikologisnya. Sehingga sebagian besar perkembangan mencakup pertumbuhan, dan juga mencakup kemunduran yang disebabkan oleh proses penuaan dan kematian.

Pada rentangan kehidupan terdapat suatu periode akhir dari masa perkembangan manusia yaitu masa tua/usia lanjut. Usia lanjut (lansia) menurut John W. Santrock (2011: 19) adalah periode perkembangan yang dimulai pada usia 60 tahunan atau 70 tahunan hingga saat kematian. Masa ini merupakan masa untuk meninjau kembali hidup yang sudah dijalani, pensiun dan menyesuaikan diri terhadap peran-peran sosial yang baru sesuai dengan menurunnya kekuatan dan kesehatan fisik dan psikis.

Perubahan yang terjadi saat memasuki masa tua memerlukan penyesuaian diri baru baik itu penyesuaian terhadap diri sendiri maupun terhadap lingkungan. Musthafa Fahmi (dalam Alex Sobur, 2003: 526) mengungkapkan penyesuaian diri merupakan upaya yang terus menerus yang bertujuan untuk merubah tingkahlaku individu agar mendapatkan hubungan yang lebih baik, serasi antara diri individu dengan lingkungannya. Lingkungan tersebut dapat mencakup semua pengaruh kemungkinan dan kekuatan yang melindungi individu, yang dapat mempengaruhi kegiatannya untuk mencapai ketenangan jiwa dan raga dalam kehidupan.

Seorang lansia yang memiliki penyesuaian diri yang baik maka akan mudah dalam memenuhi tugas perkembangannya. Karena tugas perkembangan pada masa tua ini lebih banyak kepada penyesuaian dirinya terhadap kondisi diri dan lingkungan yang baru. 
Merujuk pada hal tersebut, Elida Prayitno (2006) mengungkapkan orang-orang yang memiliki perkembangan yang sukses pada setiap periode perkembangan kehidupan mereka sebelumnya, pada periode dewasa akhir menunjukkan kepribadian yang terintegritas. Artinya mampu menyesuaikan diri dengan segala bentuk perubahan yang terjadi pada dirinya, memiliki keinginan untuk mengisi kehidupannya dengan cara meningkatkan kesempurnaan dan kegembiraan hidup dengan memanfaatkan kemampuan, pengetahuan, harta dan waktunya dengan sebaik-baiknya untuk kepentingan orang lain. Sebaliknya, orang dewasa akhir yang sulit menyesuaikan diri dengan perubahan tersebut akan merasa putus asa diakibatkan oleh perasaan, pengalaman, dan persepsi mereka yang buruk tentang kehidupan masa sekarang yang tidak menimbulkan kepuasan dan kebahagiaan dibandingkan dengan masa muda dulu. Mereka merasa tidak diberi kesempatan untuk mengaktualisasikan diri dalam berbagai bidang kehidupan, lebih banyak ditolak dari pada diterima, dan kurang dihargai oleh lingkungan sosialnya.

Berbagai masalah penyesuaian diri di masa lansia ini menimbulkan berbagai konflik dalam diri lansia tersebut, apalagi bagi lansia yang tinggal di panti sosial. Masalah yang biasanya terjadi pada lansia yang tinggal di panti sosial di antaranya tidak mau mengikuti kegiatan yang diadakan di panti, tidak patuh terhadap peraturan panti, masalah hubungan lansia dengan keluarga mereka yang kurang harmonis, tidak mau mendengarkan arahan dari pengurus panti, dan kesulitan dalam menjalin persahabatan dengan sesama penghuni panti.

Berbagai masalah memang banyak muncul ketika memasuki usia lanjut tersebut. Idealnya juga setiap masalah pasti memiliki penyelesaiannya. Permasalahan tidak mungkin dibiarkan terus-menerus karena akan mengganggu kehidupan efektif sehari-hari. Dalam menghadapi masalah tersebut sebagian individu beranggapan kalau ia bisa mengatasinya sendiri dan sebagian lagi membutuhkan pertolongan dari orang lain. Individu yang membutuhkan bantuan dalam mengatasi masalahnya dapat memanfaatkan tenaga konselor melalui pelayanan bimbingan dan konseling.

Berdasarkan permasalahan yang telah dikemukakan maka dapat dirumuskan masalah yaitu Masalah apa saja yang dialami lansia dalam menyesuaikan diri di PSTW Sabai Nan Aluih Sicincin?. Tujuan penelitian adalah (1) mendeskripsikan masalah lansia dalam melakukan penyesuaian pribadi di panti sosial, (2) mendeskripsikan masalah lansia dalam melakukan penyesuaian sosial di panti sosial.

\section{METODOLOGI PENELITIAN}

Penelitian ini merupakan penelitian deskriptif. Populasi penelitian ini adalah lansia PSTW Sabai nan Aluih Sicincin tahun 2014 yang berjumlah 110 orang dan jumlah sampel sebanyak 31 orang dengan menggunakan teknik purposive sampling. Instrumen yang digunakan untuk mengumpulkan data dalam penelitian ini adalah angket. Data dianalisis dengan menggunakan analisis persentase.

\section{HASIL}

Berdasarkan hasil pengolahan data, maka hasil penelitian tentang permasalahan yang dialami lansia dalam melakukan penyesuaian diri di panti sosial dapat digambarkan sebagai berikut:

Tabel 1. Gambaran Permasalahan Penyesuaian Pribadi Lansia di Panti Sosial

\begin{tabular}{|l|l|l|l|}
\hline No & Indikator & $\boldsymbol{f}$ & \% \\
\hline 1. & $\begin{array}{l}\text { Penyesuaian } \\
\text { terhadap perubahan } \\
\text { fisik }\end{array}$ & 5,63 & 18,15 \\
\hline $2 . \quad \begin{array}{l}\text { Penyesuaian } \\
\text { terhadap kondisi } \\
\text { psikologis }\end{array}$ & 7,86 & 25,35 \\
\hline \multicolumn{2}{|l|}{ Rata-rata } & $\mathbf{2 1 , 7 5}$ \\
\hline
\end{tabular}

Berdasarkan tabel 1 dapat dilihat permasalahan yang dialami lansia dalam melakukan penyesuaian pribadi di panti sosial sebagai berikut: permasalahan penyesuaian terhadap perubahan fisik sebesar $18,15 \%$ dan 
permasalahan penyesuaian terhadap kondisi psikologis sebesar 25,35\%. Jadi secara keseluruhan permasalahan pribadi lansia di panti sosial sebesar $21,75 \%$.

Tabel 2. Gambaran Permasalahan Penyesuaian Sosial Lansia di Panti Sosial

\begin{tabular}{|l|l|l|l|}
\hline No & Indikator & $\boldsymbol{f}$ & \% \\
\hline 1. & $\begin{array}{l}\text { Penyesuaian } \\
\text { hubungan dengan } \\
\text { sesama penghuni } \\
\text { panti }\end{array}$ & 7,29 & 23,5 \\
\hline 2. & $\begin{array}{l}\text { Penyesuaian dengan } \\
\text { hubungan } \\
\text { pengurus panti }\end{array}$ & 9,14 & 29,49 \\
\hline $3 . \quad \begin{array}{l}\text { Penyesuaian dengan } \\
\text { hubungan } \\
\text { keluarga }\end{array}$ & 6 & 19,35 \\
\hline $4 . \quad \begin{array}{l}\text { Penyesuaian dengan } \\
\text { peraturan panti }\end{array}$ & 5,86 & 18,89 \\
\hline Rata-rata & $\mathbf{2 2 , 8 1}$ \\
\hline
\end{tabular}

Berdasarkan tabel 2 dapat dilihat permasalahan yang dialami lansia dalam melakukan penyesuaian sosial di panti sosial sebagai berikut: permasalahan penyesuaian hubungan dengan sesama penghuni panti sebesar $23,5 \%$, permasalahan penyesuaian hubungan dengan pengurus panti sebesar $29,49 \%$, permasalahan penyesuaian hubungan dengan keluarga sebesar $19,35 \%$, dan permasalahan penyesuaian terhadap peraturan panti sebesar $18,89 \%$. Jadi secara keseluruhan permasalahan sosial lansia di panti sosial sebesar 22,81\%.

Kemudian, untuk melihat keseluruhan permasalahan yang dialami lansia dalam melakukan penyesuaian diri di panti sosial dapat dilihat pada tabel berikut ini:

Tabel 3.Gambaran Keseluruhan Permasalahan Penyesuaian Diri Lansia di Panti Sosial

\begin{tabular}{|l|l|l|l|}
\hline No & Sub Variabel & $\boldsymbol{f}$ & $\mathbf{\%}$ \\
\hline 1. & $\begin{array}{l}\text { Masalah } \\
\text { penyesuaian } \\
\text { pribadi }\end{array}$ & 6,75 & 21,75 \\
\hline 2. & $\begin{array}{l}\text { Masalah } \\
\text { penyesuaian sosial }\end{array}$ & 7,07 & 22,81 \\
\hline Rata-rata & & $\mathbf{2 2 , 2 8}$ \\
\hline
\end{tabular}

Berdasarkan tabel 3 dapat dilihat permasalahan yang dialami lansia dalam melakukan penyesuaian diri di panti sosial sebagai berikut: permasalahan yang dialami lansia dalam melakukan penyesuaian pribadi sebesar $21,75 \%$, dan permasalahan yang dialami lansia dalam melakukan penyesuaian sosial sebesar $22,81 \%$. Jadi secara keseluruhan permasalahan yang dialami lansia dalam melakukan penyesuaian diri di panti sosial adalah 22,28\%.

\section{PEMBAHASAN}

\section{A. Penyesuaian Pribadi Lansia}

Dari hasil penelitian terungkap bahwa permasalahan tertinggi dalam penyesuaian pribadi yaitu pada aspek penyesuaian terhadap perubahan psikologis sebesar 25,35\%. Hal ini bertolak belakang dengan pendapat Diane E. Papalia, dkk (2008) yang mengungkapkan bahwa lansia yang tinggal di panti sosial dengan berbagai pelayanan yang diberikan memiliki harga diri yang tinggi, depresi yang lebih rendah dan perasaan puas yang lebih besar serta kebermaknaan dalam hidup, hal ini dikarenakan penyesuaian psikologis yang memotivasi mereka untuk hidup dan merawat diri secara lebih baik di bandingkan dengan tinggal rumah masing-masing.

Enung Fatimah (2006: 207) menambahkan keberhasilan penyesuaian pribadi ditandai dengan tidak adanya rasa benci, lari dari kenyataan dan tanggung jawab, dongkol, kecewa, atau tidak percaya pada kondisikondisi yang dialaminya. Sebaliknya, kegagalan dalam penyesuaian pribadi ditandai dengan guncangan emosi, 
kecemasan, ketidakpuasan dan keluhan terhadap nasib, yang disebabkan adanya kesenjangan antara individu dengan tuntutan lingkungan, sehingga lansia yang mengalami masalah tersebut harus melakukan penyesuaian diri.

Keadaan mental yang sehat merupakan syarat bagi tercapainya penyesuaian diri yang baik, sehingga dapat dikatakan bahwa adanya frustrasi, kecemasan dan cacat mental akan dapat melatarbelakangi adanya hambatan dalam penyesuaian diri.

Oleh karenanya lansia yang mengalami masalah pada penyesuaian terhadap kondisi psikologis ini perlu mendapat perhatian dari konselor dengan memberikan berbagai layanan bimbingan dan konseling di antaranya layanan informasi tentang cara mengelola emosi di masa tua maupun layanan konseling perorangan. Pengurus panti juga dapat lebih memperhatikan kebutuhan psikologis lansia selama tinggal di panti dengan mengadakan kegiatan-kegiatan yang menyenangkan seperti kegiatan senam pagi, kegiatan kesenian, maupun kegiatan lain yang bisa dimanfaatkan lansia sebagai penyalur hobi, sehingga lansia bisa terhindar dari perasaan negatif selama tinggal di panti.

Kemudian lansia yang mengalami masalah pada penyesuaian terhadap perubahan fisik yaitu sebesar $18,15 \%$. Berdasarkan tugas-tugas perkembangan masa tua yang dikemukakan oleh Havigurst (dalam Elizabeth B. Hurlock, 1980: 10) yang salah satunya adalah menyesuaikan diri dengan menurunnya kekuatan fisik dan kesehatan. Meskipun penurunan kekuatan fisik saat memasuki usia tua merupakan suatu hal yang wajar namun perubahan tersebut juga membutuhkan penyesuaian baru. Dengan menurunnya kekuatan fisik tersebut kemungkinan terkena penyakit cenderung meningkat dan juga mengganggu kelancaran dalam melakukan aktifitas sehari-hari seperti berpakaian, mandi, berjalan dan sebagainya.

Beberapa cara yang dapat dilakukan lansia dalam menyesuaikan diri dengan penurunan kesehatan dan kekuatan fisik yang dikemukakan oleh Diane E. Papalia, dkk (2009) yaitu dengan melakukan aktifitas fisik dan pengaturan gizi. Aktifitas fisik yang bisa dilakukan lansia untuk menunjang kesehatan seperti senam dan olahraga ringan, sedangkan pengaturan gizi dengan mengatur pola makan sehari-hari.

Oleh karena itu, peran konselor dan pengurus panti juga dapat membantu lansia dalam menyesuaikan diri terkait dengan perubahan fisik yang mereka alami, salah satunya dengan rutin melakukan kegiatan olahraga seperti senam pagi ataupun aktifitas fisik lainnya agar lansia tetap aktif bergerak dan mencegah terjadinya masalah pada penurunan kesehatan atau kekuatan fisik.

\section{B. Penyesuaian Sosial Lansia}

Penyesuaian sosial terjadi dalam lingkup hubungan sosial tempat individu berinteraksi dengan orang lain. Berdasarkan hasil penelitian permasalahan yang dialami lansia dalam melakukan penyesuaian sosial tertinggi yaitu pada penyesuaian hubungan lansia dengan pengurus panti sebesar $29,49 \%$. Selama tinggal di panti sosial hubungan sosial yang terjalin tidak hanya dengan sesama penghuni panti saja tetapi juga hubungan sosial dengan pengurus panti. Lansia yang mengalami masalah dalam menjalin hubungan sosial dengan pengurus panti akan mengakibatkan lansia tersebut bersikap tidak menghargai, melawan, takut dan berusaha menghindar.

Untuk itu selama lansia tinggal di panti sosial diharapkan adanya hubungan sosial yang harmonis yang terjalin antara lansia dengan pengurus panti, karena jika hubungan tersebut terjalin dengan baik maka lansia akan menjalani kehidupan sosial yang menyenangkan dan tidak akan ada lagi perasaan takut dengan pengurus panti, ataupun berusaha untuk melawan jika pengurus panti menegur karena kesalahan yang dilakukan lansia.

Bantuan dari konselor dan pengurus panti dibutuhkan untuk membantu lansia dalam menyesuaikan diri dengan kehidupan sosial di lingkungan panti seperti menyelenggarakan layanan informasi tentang mengembangkan sikap saling menghormati, melaksanakan layanan konseling individual kepada lansia yang mengalami masalah. Untuk pengurus panti dapat memberikan pengetahuan tentang struktur organisasi yang ada di panti, memberikan pelayanan yang optimal kepada lansia, melaksanakan kegiatan bersama antara pengurus dan penghuni panti, dan sebagainya.

Kemudian lansia yang mengalami masalah pada penyesuaian hubungan dengan sesama penghuni panti yaitu sebesar 23,5\%. Hal ini menandakan bahwa dalam menjalin hubungan sosial dengan sesama penghuni panti, lansia tidak mampu mengarahkan diri dan menerima setiap perbedaan-perbedaan yang dimiliki oleh lansia lainnya. 
Dalam kaitannya dengan hal tersebut, Abu Ahmadi (2009: 49) mengungkapkan kehidupan manusia dalam masyarakat mempunyai dua fungsi yaitu berfungsi sebagai objek dan subjek. Jika manusia hanya sebagai objek maka hidupnya tidak mungkin lebih tinggi daripada kehidupan benda-benda mati dan tidak akan timbul kemajuan. Sebaliknya, manusia hanya sebagai subjek saja maka ia tidak mungkin bisa hidup bermasyarakat. Untuk itu apabila manusia mampu berfungsi keduanya senantiasa mereka dapat dikatakan mampu untuk hidup bermasyarakat dan menyesuaikan diri. Begitupun dengan penyesuaian diri lansia dengan lansia lainnya, dibutuhkan rasa penerimaan dan penghargaan dari masing-masing lansia.

Sejak awal kehidupan seseorang, hubungan sosial dan kesehatan berjalan beriringan. Diane E. Papalia (2009) menjelaskan dukungan emosional dapat membantu lansia dalam mempertahankan kepuasan hidup ketika menghadapi stres dan trauma, dan ada kaitan positif dengan kesehatan dan kebahagiaan hidup yang lebih baik. Sebaliknya hubungan yang penuh konflik memainkan peran negatif yang lebih besar seperti lansia yang mengalami masalah dalam sebuah hubungan pertemanan setidaknya bisa menjadi sebagian dari sumber masalah lain seperti masalah kesehatan karena stres yang meningkat.

Lansia yang memiliki lingkaran pertemanan yang aktif cenderung lebih sehat dan bahagia. Mereka bisa membagi perasaan, pemikiran, kekhawatiran, dan kesulitan mereka dengan teman cenderung akan menghadapi perubahan dan krisis karena penurunan kesehatan dengan lebih baik dan hidup lebih lama. Untuk itu lansia yang mampu menyesuaiakan diri dengan hubungannya dengan sesama penghuni panti akan menjadikan kehidupan selama tinggal di panti lebih menyenangkan dan dapat mempengaruhi kondisi fisik dan psikis lansia itu sendiri.

Dengan adanya permasalahan lansia tersebut, maka diharapkan bantuan dari konselor dan pengurus panti. Konselor dapat mengadakan kegiatan bimbingan kelompok yang dapat meningkatkan hubungan mereka melalui dinamika kelompok dan juga layanan informasi tentang pentingnya menjalin persahabatan. Selain itu pengurus panti juga dapat menyelenggarakan kegiatan yang dapat meningkatkan hubungan lansia dengan sesama lansia agar terjalin dengan baik.

\section{Implikasi terhadap Layanan Bimbingan dan Konseling}

Temuan penelitian mengungkapkan bahwa beberapa lansia mengalami permasalahan dalam melakukan penyesuaian diri di panti sosial. Oleh karena itu peran konselor masyarakat sangat dibutuhkan dalam upaya pencegahan, pengentasan dan pengembangan agar lansia dapat melakukan penyesuaian diri yang baik selama tinggal di panti sosial. Beberapa layanan bimbingan dan konseling yang dapat diberikan, yaitu:

\section{Layanan Informasi}

Dalam menjalani kehidupan dan juga perkembangan diri, individu memerlukan berbagai informasi baik untuk kebutuhannya saat ini maupun untuk kehidupan ke depannya. Oleh karena itu layanan informasi dalam layanan bimbingan dan konseling berusaha memenuhi kekurangan individu akan informasi yang diperlukan apalagi untuk mereka yang telah berusia lanjut.

Berdasarkan hasil penelitian diketahui $21,75 \%$ lansia mengalami masalah pada penyesuaian pribadi terkait dengan penyesuaian terhadap perubahan fisik dan psikologis, untuk itu layanan informasi yang dapat diberikan konselor meliputi:

a. Cara merawat kesehatan tubuh untuk lansia.

b. Mengelola emosi yang positif di usia senja.

c. Pentingnya mengatur pola makan yang sehat.

d. Meningkatkan kebahagiaan di usia senja.

Kemudian masalah yang dialami lansia dalam penyesuaian sosial yang berdasarkan hasil penelitian diketahui $22,81 \%$, dapat diberikan layanan informasi yang meliputi:

a. Cara meningkatkan disiplin di lingkungan panti.

b. Menjalin hubungan sosial yang positif di lingkungan baru.

c. Meningkatkan kemampuan bekerjasama dengan sesama penghuni panti.

d. Mengembangakn kemampuan berkomunikasi yang baik.

2. Layanan Konseling Individual

Menurut Dewa Ketut Sukardi dan Nila Kusmawati (2008: 62) konseling individual yaitu pelayanan bimbingan dan konseling yang memungkinkan konseli/klien mendapatkan pelayanan lansung tatap muka 
(secara perorangan) dengan konselor dalam rangka pembahasan dan pengentasan permasalahan pribadi yang dideritanya.

Konselor dapat menyelenggarakan layanan konseling individual kepada lansia yang mengalami masalah dengan adanya kesukarelaan dan keterbukaan dari klien/lansia untuk menceritakan masalah yang dialami sehingga dapat terentaskannya masalah tersebut.

\section{Layanan Bimbingan Kelompok}

Layanan bimbingan kelompok merupakan salah satu jenis layanan Bimbingan dan Konseling yang ditujukan kepada beberapa orang dengan memanfaatkan dinamika kelompok untuk memperoleh berbagai macam informasi dan pemahaman baru dari topik yang dibahas.

Menurut Samsul Munir Amin (2010: 291) melalui layanan bimbingan kelompok para anggota kelompok diajak untuk bersama-sama mengemukakan pendapat tentang sesuatu dan membicarakan topiktopik penting, mengembangkan langkah-langkah bersama untuk menangani permasalahan yang dibahas dalam kelompok. Dengan demikian, selain dapat menghasilkan hubungan baik di antara anggota kelompok, meningkatkan kemampuan berkomunikasi antarindividu, memperoleh pemahaman berbagai situasi dan kondisi lingkungan, juga dapat mengembangkan sikap dan tindakan nyata untuk mencapai halhal yang diharapkan.

Untuk itu, usaha yang dapat dilakukan oleh konselor dalam membantu mengatasi masalah penyesuaian diri pada lansia yang tinggal di panti sosial yaitu dengan menyelenggarakan bimbingan kelompok dengan topik tugas yang membahas tentang masalah penyesuaian diri maupun hal-hal yang berkaitan dengan penyesuaian diri tersebut.

\section{KESIMPULAN DAN SARAN}

A. Kesimpulan

Berdasarkan hasil penelitian diperoleh data bahwa permasalahan yang dialami lansia dalam melakukan penyesuaian diri di panti sosial yaitu:

1. Sekitar $21,75 \%$ lansia mengalami masalah pada penyesuaian pribadi. Data tersebut menunjukkan kurang dari seperempat persen lansia mengalami masalah pada penyesuaian pribadi yang meliputi masalah penyesuaian terhadap perubahan fisik dan masalah penyesuaian terhadap kondisi psikologis.

2. Sekitar $22,81 \%$ lansia mengalami masalah pada penyesuaian sosial. Data tersebut menunjukkan kurang dari seperempat persen lansia mengalami masalah pada penyesuaian sosial yang meliputi masalah penyesuaian hubungan dengan sesama penghuni panti, masalah penyesuaian hubungan dengan pengurus panti, masalah penyesuaian hubungan dengan keluarga, dan masalah penyesuaian dengan peraturan panti sosial.

\section{B. Saran}

Berdasarkan hasil penelitian, maka dapat dikemukakan beberapa saran, yaitu:

1. Diharapkan kepada keluarga lansia agar tetap memberikan perhatian dan motivasi sehingga lansia mampu mengarahkan diri dan mengembangkan kemampuan menyesuaikan diri dengan baik di panti sosial.

2. Diharapkan kepada pengurus panti sosial agar dapat mengoptimalkan pelayanan dan juga melakukan pendekatan kepada lansia sehingga lansia merasa nyaman dan diperhatikan selama mereka tinggal di panti sosial.

3. Diharapkan kepada konselor agar dapat membantu lansia yang mengalami masalah dalam penyesuaian diri di panti sosial dengan cara memberikan layanan bimbingan dan konseling sesuai dengan kebutuhan lansia.

4. Diharapkan kepada peneliti selanjutnya agar dapat memperkuat penelitian ini dan mengungkap serta meneliti variabel lain yang berkontribusi terhadap penyesuaian diri lansia di panti sosial seperti optimalisasi pelayanan bimbingan dan konseling untuk meningkatkan penyesuaian diri lansia di panti sosial dan faktor-faktor penyebab timbulnya masalah penyesuaian diri pada lansia di panti sosial.

\section{DAFTAR PUSTAKA}

Abu Ahmadi. 2009. Psikologi Sosial. Jakarta: Rineka Cipta.

Alex Sobur. 2003. Psikologi Umum. Bandung: Pustaka Setia. 
Dewa Ketut Sukardi dan Nila Kusmawati. 2008. Proses Bimbingan dan Konseling di Sekolah. Jakarta: Rineka Cipta.

Diane E. Papalia. dkk. 2008. Human Development (Psikologi Perkembangan). Alih Bahasa: A.K. Anwar. Jakarta: Kencana.

Diane E. Papalia. dkk. 2009. Human Development (Psikologi Perkembangan). Alih Bahasa: A.K. Anwar. Jakarta: Salemba Humatika.

Elida Prayitno. 2006. Psikologi Dewasa. Padang: Angkasa Raya.

Elizabeth B. Hurlock. 1980. Psikologi Perkembangan. Alih Bahasa: Istiwidayandi \& Soedjarwo. Jakarta: Erlangga.

Enung Fatimah. 2006. Psikologi Perkembangan. Bandung: Pustaka Setia.

John W. Santrock. 2012. Life-Span Development. (Edisi ke-13. Terjemahan). Jakarta: Erlangga.

Samsul Munir Amin. 2010. Bimbingan dan Konseling Islam. Jakarta: Amzah. Hidup Anda. Jakarta: Bumi aksara 